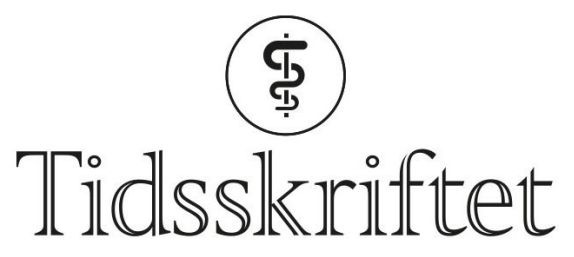

DEN NORSKE LEGEFORENING

\title{
Strålebehandling etter prostatektomi
}

FRA ANDRE TIDSSKRIFTER

PETTER MORTEN PETTERSEN

Tidsskriftet

Pasienter som får postoperativ strålebehandling etter radikal prostatektomi ved prostatakreft, får oftere vannlatingsplager enn dem som stråles først ved tegn til residiv.

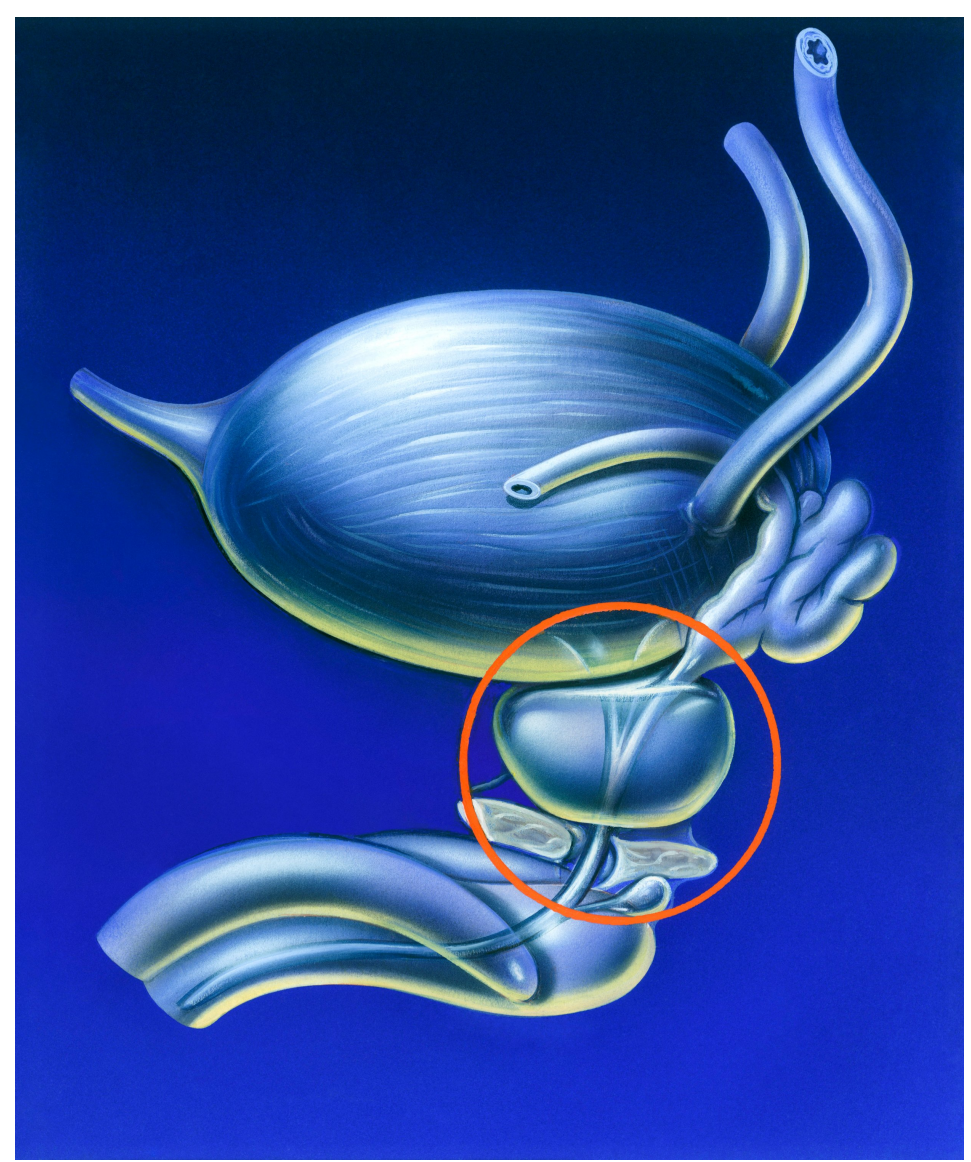

Illustrasjon: Science Photo Library / NTB

Strålebehandling av prostatakreft kan benyttes både som primær- og tilleggsbehandling til kirurgi. Pasienter som behandles med radikal prostatektomi, kan få postoperativ strålebehandling eller hormonbehandling dersom det er holdepunkter for eller sterk mistanke om at ikke alt svulstvev er fjernet. Mistanken baserer seg som regel på at PSAnivået begynner å stige etter operasjonen, såkalt PSA-residiv. Lokal strålebehandling som gis etter en radikal prostatektomi ved prostatakreft, kalles på engelsk salvage therapy, og kan oversettes med redningsbehandling. 
I en stor multisenterstudie ble rundt 1400 pasienter som fikk utført radikal prostatektomi pga. prostatakreft, randomisert til strålebehandling enten postoperativt eller ved tegn til residiv (1). Andelen pasienter som fikk tegn til residiv innen 5 år var omtrent lik i de to gruppene ( $85 \%$ og $88 \% ; p=0,56$ ). Det samme gjaldt andelen som unngikk hormonbehandling (93\% og $92 \%$ ). Inkontinens etter ett år var hyppigere blant dem som fikk postoperativ strålebehandling enn blant dem som fikk strålebehandling først ved tegn til residiv (inkontinenskår hhv. 4,8 og 4,0; $\mathrm{p}=\mathrm{o}, 0023)$. Andelen som fikk uttalt uretrastriktur innen to år var også noe høyere (6\% versus $4 \%$ ).

- Denne studien viser at strålebehandling som gis før sfinkterapparatet er helt restituert etter radikal prostatektomi, vil forverre pasientens vannlatingsproblemer, sier professor Truls E. Bjerklund Johansen, som er overlege ved Urologisk avdeling, Oslo universitetssykehus. Flere studier har vist at strålebehandling mot lokalt residiv av prostatakreft etter radikal prostatektomi bedrer overlevelsen. I Norge får de fleste pasienter som har fått utført radikal prostatektomi for prostatakreft strålebehandling først når det blir konstatert residiv, dvs. når PSA-nivået begynner å stige etter operasjonen, sier Bjerklund Johansen.

\section{LITTERATUR:}

1. Parker CC, Clarke NW, Cook AD et al. Timing of radiotherapy after radical prostatectomy (RADICALSRT): a randomised, controlled phase 3 trial. Lancet 2020; 396:1413-21. [PubMed][CrossRef]

Publisert: 22. mars 2021. Tidsskr Nor Legeforen. DOI: 10.4045/tidsskr.21.0056

(C) Tidsskrift for Den norske legeforening 2020. Lastet ned fra tidsskriftet.no 